\title{
Koostöö kutseõpetaja professionaalsust määrava tegurina
}

\author{
Meidi Sirk $^{\mathrm{a} 1}$, Meril Ümarik ${ }^{\mathrm{a}}$, Krista Loogma ${ }^{\mathrm{a}}$, Katrin Niglas ${ }^{\mathrm{b}}$ \\ ${ }^{a}$ Tallinna Ülikooli haridusteaduste instituut \\ ${ }^{b}$ Tallinna Ülikool
}

\begin{abstract}
Annotatsioon
Eesti haridusmaastikul toimunud reformid on toonud kaasa muutused õpetajate professionalismis ja professionaalsuses. Hargreaves (2006) eristab õpetajate professionalismi ajajärke ja osutab, et tänapäeval on autonoomiaperiood asendunud kollegiaalse koostöö ajajärguga. Hoyle (1974) vastandab oma professionaalsuse mudelis autonoomia ja koostöö, eristades seejuures piiratud ja avaravaatelist professionaalsust. Artikli eesmärk ongi mõista kutseõpetajate professionaalsust kollegiaalse professionalismi ajajärgul. Analüüs põhineb kõikse küsitlusuuringu andmestikul, mille sihtrühma moodustasid kutseõpetajad. Vastused saadi 501 kutseõpetajalt. Andmete analüüsimisel rakendati klasteranalüüsi, tuginedes Hoyle’i professionaalsuse mudelile. Kutseõpetajate professionaalsust iseloomustava koostöö ulatuse alusel eristus kolm klastrit: ulatuslikult võrgustunud, omaette hoidvad ja koolikesksed professionaalid. Uurimistulemustest selgus, et esimesse klastrisse kuuluvad õpetajad on teistega võrreldes enam rahul oma töö ja valitud ametiga.
\end{abstract}

Võtmesõnad: haridusmuutused, autonoomia, koostöö, professionaalsus, professionalism, kutseõpetajad, klasteranalüüs

\section{Sissejuhatus}

Standardiseerimine, koolide ja õpetajate üha kasvav aruandluskohustus, kuid samas nõue toetada õppijate innovaatilisust ja loovust (Sahlberg, 2010) esitavad õpetajatööle vastuolulisi nõudmisi. Kutseõpetaja töö on iseseisvusaja jooksul palju muutunud. Endistest teooriaõpetajatest ja õppemeistritest on saanud kutseõpetajad (Kutseõpetaja statuut, 1995), kes peavad peale erialaste õpingute lõimima ka erialaõppe ja üldainete teemasid. Õpetamine on muutunud

Haridusteaduste instituut, Tallinna Ülikool, Narva mnt 25, 10120 Tallinn; meidi.sirk@tlu.ee 
oma sisult komplekssemaks ja reguleeritumaks, tuginedes rangelt riiklikele õppekavadele ja kutsestandarditele. Üha suurema osa kutseõpetajate igapäevatööst moodustavad mitmesugused aeganõudvad ülesanded, nagu suurenenud administratiivne töö, kursusejuhendamisega seotud ülesanded, õpilaste ettevalmistamine kutsemeistrivõistlusteks, mistõttu tunnetavad paljud kogenud kutseõpetajad, et õpetamine on nende professionaalses töös muutunud teisejärguliseks (Sirk, Liivik, \& Loogma, 2016). Reformidega kaasnenud struktuurimuutuste keskel on kutseõpetajad ise aktiivsed oma kutse konstrueerimisel, suhtudes valikuliselt muutustesse, mis toovad kaasa rollimuutusi nende kutsetöös. Näiteks suhtuvad nad valdavalt positiivselt üha laienevasse koostöösse ja võrgustumisse ning enamasti ka näiteks õppekavas tehtavatesse muudatustesse (ibid.). Suurimaks katsumuseks peavad kutseõpetajad õpilaskonnas toimuvaid muutusi, sh õpilaskonna laienemist ja diferentseerumist: kutseõppijate hulka kuuluvad nii põhikooli katkestanud kui ka kõrgkooli lõpetanud õppijad. Lisaks tuntakse kodude vähest toetust, eriti aga põhikooli lõpetanud õpilaste suuri õpi- ja käitumisraskusi (Liivik \& Sirk, 2015; Sirk et al., 2016), mis loob suurenenud nõudmised kutseõpetajate sotsiaalpedagoogilistele ja psühholoogilistele pädevustele (Cort, 2011; Harris, Simons, \& Clayton, 2005; Kirpal, 2011). Muutunud õpilaskond on toonud kaasa kutseõpetajate uusi rolle, nagu juhendaja, mentor, nõustaja, sotsiaaltöötaja (Cort \& Rolls, 2010; Hughes \& Attwell, 2010; Kats, van Lakerveld, \& Smit, 2010; Sirk et al., 2016; Susimetsä, 2010; Tutschner, 2010; Ümarik \& Rekkor, 2013), mõjutades nende professionaalsust (Sirk et al., 2016) ja identiteeti (Ümarik \& Rekkor, 2013). Kasvanud on vajadus teha aktiivset koostööd nii koolisiseste kui ka -väliste huvipooltega (Sirk et al., 2016).

Muutunud töö ja mitmekesistunud rollid tingivad vajaduse kutseõpetajate professionalismi ja professionaalsuse ümbermõtestamise järele. Varasematel perioodidel on õpetajate professionalismi käsitletud seoses autonoomiaga, kuid tänapäeva muutuste kontekstis on üha olulisemaks teguriks õpetajate töös kujunenud koostöö. Hargreaves (2006) rõhutab, et periood, kus õpetajate professionalismi määras autonoomia, on lõppenud ning asendunud kollegiaalse koostöö ajajärguga. Hoyle (1974) eristab õpetajate professionalismi ja professionaalsust ning näeb viimast kui professionalismi ühte atribuuti. Ta osutab oma mudelis, et koostöised tegevused vähendavad õpetaja autonoomiat. Samas võime näha, et ka kollegiaalse koostöö ajajärgul leidub õpetajaid, kes ignoreerivad koostööd ja eelistavad tegutseda autonoomselt (Hargreaves, 2006). Sama on ilmnenud ka meie varasematest uuringutest (Rekkor, Ümarik, \& Loogma, 2013; Tafel-Viia, Loogma, Lassur, \& Roosipõld, 2012). Koostöö ja autonoomia teema on oluline ka seoses haridusmuutustega. On leitud, et koostöö ja koostöine õppimine, sh õpetajate professionaalsed kogukonnad, toetavad haridusmuutustega kohanemist, nende mõtestamist ja omaksvõttu (Brouwer, Brekelmans, Nieuwenhuis, 
\& Simons, 2012; Daly, Nienke, Bolivar, \& Burke, 2010; Spillane, Reiser, \& Reimer, 2002; Ümarik, 2015). Näeme sageli, et planeeritud haridusreformid ei ole rakendunud selles ulatuses, nagu oli kavandatud, või toonud kaasa oodatud muutusi (Hargreaves \& Goodson, 2006; Wallace, 2003).

Käsitledes õpetajat kui keskset toimijat (agency) haridusmuutuste protsessis, on oluline analüüsida koostööd kui ühte õpetajate professionalismi keskset tahku. Artikli eesmärk on mõista kutseõpetajate professionaalsust kollegiaalse professionalismi ajajärgul. Uurimuses otsime vastust küsimusele, milliseid kutseõpetajate gruppe võib eristada koostöö ulatuse põhjal. Võttes aluseks Hoyle'i piiratud ja avaravaatelise professionaalsuse mudeli, konstrueerime kutseõpetajate klastrid, kirjeldame neid ning analüüsime, kuidas hindavad erineva koostöö ulatusega kutseõpetajad tööga rahulolu ja oma kutse staatust ühiskonnas. Analüüsis toetume kutseõpetajate hulgas tehtud küsitlusuuringu andmestikule, mis hõlmab 501 kutseõpetaja vastuseid.

\section{Õpetajate professionalismi ja professionaalsuse teoreetilised käsitlused}

Kiired ühiskondlikud muutused, kasvanud ootused ja suurenenud õpetajatöö regulatsioon on kutsunud esile diskussioone õpetajate professionalismi ja professionaalsuse kontseptsioonide üle ning vajaduse neid ümber mõtestada (Clow, 2001; Evans, 2008; Evetts, 2009; Hargreaves, 2006; Loogma, 2014; Noordegraaf, 2007; van Ruler, 2005). Kõige laiemalt käsitletakse professionalismi kui sotsiaalselt konstrueeritud arusaama professioonist (Freidson, 2001) ning professionaalsust kui õpetaja enda arusaama õpetajakutsest (Goodson, 2003).

Traditsioonilise professionalismi käsitluse järgi iseloomustab ametigruppi, mida saab nimetada professiooniks, kõrge staatus ühiskonnas, eneseregulatsioon, autonoomia ja kontroll oma töö sisu üle, akadeemiline haridus, kontroll ametigruppi sisenemise üle ja spetsiifiline professionaalne ideoloogia (Freidson, 2001). Professionalism on otseselt seotud mõistega professioon (elukutse) ning näitab, millised ülesanded, tegevused ja normid kuuluvad elukutse juurde ning millised mitte (Loogma, 2014; Noordegraaf, 2007; van Ruler, 2005). Nii kuuluvad traditsiooniliste professioonide hulka juristid, arstid, advokaadid. Neid on nimetatud ka klassikalises mõttes selgeteks (pure), tugevateks (strong) või tõelisteks (real) professioonideks (Noordegraaf, 2007). Õpetajate kutset on peetud pigem semiprofessiooniks (Antikainen, Rinne, \& Koski, 2009) või on see seatud professioonina üldse kahtluse alla (Clow, 2001). Tavapäraselt käsitletakse professionalismi kui ajas muutuvat ja sotsiaalselt konstrueeritud nähtust (Evans, 2008; Evetts, 2009; Hargreaves, 2006). 
Hargreaves (2006) eristab nelja õpetajate professionalismi ajajärku. Eelprofessionalismi ajajärgul ópetas õpetaja aineid traditsioonilisel viisil, lähtudes standardiseeritud õppekavadest. Olulisimaks peeti õpetajate aineteadmiste taset ning õpetajaks kujunemise peamiseks teeks oli meistri-õpipoisi mudeli rakendamine ehk vanema kolleegi töö vaatlemine. Järgmisel ehk autonoomse professionalismi ajajärgul (1960ndatel ehk kuldsel ajastul) toimus õpetajate ettevalmistus üha enam ülikoolides. Õpetajad nautisid pedagoogilist vabadust õppekavade arendamisel, riiklike korralduste täitmisel ning otsustusprotsessides, millega kaasnes ametialane usaldus, turvalisus ja professionaalne väärikus. Klassiruumi kontekstis iseloomustas selle ajastu õpetamiskultuuri õpetajate individualism, isoleeritus ja privaatsus. Üha suurenev komplekssus hariduses, reformid ning õpetajatööd mõjutavad muutused tõid kaasa kollegiaalse koostöö ajajärgu, mida Hargreaves seostab 1980. aastate keskpaigaga. Mitmekesised haridusmuutused, õpetamismeetodite mitmekesisus, lisandunud sotsiaaltöötaja roll ja erivajadustega õppijate osakaalu kasv tekitasid õpetajates tööalast ebakindlust ning vajaduse suurema kollegiaalse koostöö ja õppimise järele. Postmodernsel (või professionalismijärgsel) ajajärgul on kool tugevasti mõjutatud globaalmajanduslikust konkurentsist. Õpetajate otsustusõiguse kahanemisega on kaasnenud suurem vastutus õpilaste hariduslike probleemide eest, mis aga on kokkuvõttes vähendanud õpetajate autonoomiat. Et vältida naasmist esimesse ajajärku, pakub Hargreaves välja alternatiivi - mõtestada ja kujundada uut ópetajate professionalismi, mis on avatud, kaasav ja demokraatlik. Lisaks peaks õpetajate kutset iseloomustama teaduspõhine haridus, kõrge staatus ja konkurentsivõimeline palk. Hargreaves (2006) juhindub oma ajajärkude kirjeldamisel professionalismi kontseptsioonist, mis seondub õpetajakutse staatusega ühiskonnas. Võib eeldada, et individuaalsel tasandil võivad õpetajad õpetajakutse tähendust erinevalt mõista.

Hoyle (1974) eristab oma käsitluses õpetajate professionalismi ja professionaalsust ning näeb viimast kui üht professionalismi atribuuti, mis on seotud eelkõige õpetajatöö individuaalsete elementidega, nagu teadmised, oskused, protseduurid, mida ta oma praktikas rakendab. Hoyle'i professionaalsuse mudelis vastanduvad piiratud (restricted) ja avaravaateline (extended) professionaalsus (vt tabel 1). Mudeli kohaselt on piiratud professionaal autonoomne õpetaja, kes lähtub oma töös kogemusest ja intuitsioonist ning juhindub kitsast klassiruumi perspektiivist ja igapäevasest õpetamispraktikast. Seevastu avaravaateline professionaal omab laiemat arusaama hariduse olemusest ja rollist ühiskonnas, väärtustades teoreetilisi teadmisi ja loovust ning mõtestades oma tööd ja rolli õppija elutee kujundamisel. Avaravaatelist professionaali iseloomustab koostöös õpetamine ja otsustamine: ühises meeskonnas arendatakse õppekavasid, valitakse meetodeid ja õppematerjale. Hoyle vastandab koostööd 
ja autonoomiat, teisisõnu, õpetajad kaotavad koostööd tehes autonoomiat, kuna kaob kontroll oma õpetamistegevuse üle (Hoyle, 1974, 2008).

Tabel 1. Hoyle'i piiratud ja avaravaatelise professionaalsuse mudel

\begin{tabular}{l|l}
\hline \multicolumn{1}{c|}{$\begin{array}{c}\text { Piiratud professionaalsus } \\
\text { (restricted professionality) }\end{array}$} & \multicolumn{1}{c}{$\begin{array}{c}\text { Avaravaateline professionaalsus } \\
\text { (extended professionality) }\end{array}$} \\
\hline Oskuste omandamine praktikast & $\begin{array}{l}\text { Oskuste omandamine teooria ja praktika } \\
\text { kombineerimisel }\end{array}$ \\
\hline $\begin{array}{l}\text { Õpetamise fookus hetkeolukorral (siin ja } \\
\text { praegu) }\end{array}$ & $\begin{array}{l}\text { Hariduse tajumine laiemas sotsiaalses } \\
\text { kontekstis (õpetaja rolli laiem tajumine) }\end{array}$ \\
\hline Klassiruumis toimuva tajumine isolatsioonis & $\begin{array}{l}\text { Klassiruumis toimuva tajumine laiema } \\
\text { kooli- ja hariduspoliitika osana }\end{array}$ \\
\hline Õppemeetodite arendamine isolatsioonis & $\begin{array}{l}\text { Õppemeetodite võrdlemine kolleegide } \\
\text { omadega }\end{array}$ \\
\hline Autonoomia säilitamine oma töös & Kollegiaalse koostöö väärtustamine \\
\hline $\begin{array}{l}\text { Vähene osalemine igapäevatööd otseselt } \\
\text { mittepuudutavates tegevustes (sh profes- } \\
\text { sionaalsetes tegevustes, nagu võrgustikud, } \\
\text { erialaliidud) }\end{array}$ & $\begin{array}{l}\text { Sage osalemine igapäevatööd otseselt } \\
\text { mittepuudutavates tegevustes } \\
\text { (sh professionaalsetes tegevustes, nagu } \\
\text { võrgustikud, erialaliidud) }\end{array}$ \\
\hline Harv erialakirjanduse lugemine & Sage erialakirjanduse lugemine \\
\hline $\begin{array}{l}\text { Vähene haaratus oma professionaalsuse } \\
\text { arendamisel, peamiselt praktikaga seotud } \\
\text { kursused }\end{array}$ & $\begin{array}{l}\text { Laiem haaratus oma professionaalsuse } \\
\text { arendamisel, sh teoreetilised kursused }\end{array}$ \\
\hline $\begin{array}{l}\text { Õpetamise tajumine intuitiivse tegevusena } \\
\text { Orpetamise tajumine ratsionaalse } \\
\text { tegevusena }\end{array}$ \\
\hline
\end{tabular}

Evans (2008), arendades Hoyle'i mudelit edasi, käsitleb piiratud ja avaravaatelist professionaalsust mitte kui ideaalmudeleid, vaid kontiinumi otspunkte, mille telje eri punktidesse paigutuvad õpetajad oma professionaalsuse orientatsiooni alusel. Erinevalt Hoyle'i (1974) professionaalsuse käsitlusest, milles vastandati autonoomiat ja koostöisust, on teised autorid (Evetts, 2002; Pearson \& Moomaw, 2006) pakkunud välja uue lähenemise autonoomiale. See ei põhine individuaalsetel alustel, vaid kollektiivsel otsustamisel ning tähendab õpetajate õigust langetada otsuseid koostöös näiteks õppekavade arendamisega, erinevate juhistega või koolipoliitikaga seotud küsimustes. Võib eeldada, et autonoomia tähendus õpetajate töös on muutunud, kuid indiviidide tasandil võib paralleelselt kehtida nii vana kui ka tänapäevane arusaam õpetajate autonoomiast (Pearson \& Moomaw, 2006). 
Evetts (2002) pakub välja, et võiksime asendada autonoomia mõistega valikuvabadus. Professionaalne valikuvabadus on seotud otsuste tegemisega oma töös, mis tähendab vabadust iseseisvalt hinnata ja analüüsida olukordi ning tõestada oma otsuste õigsust, tuginedes asjakohastele õigusaktidele, mis tegelikkuses õpetajate tegevust piiravad (ibid.). Teisisõnu, kollegiaalsel otsustamisel peaks säilima teatud valikuvabadus, mille piires professionaalid langetavad otsuseid, lähtudes oma asjatundlikkusest, kuid ka raamidest, mis neid piiravad. Asetades selle käsitluse kutseõpetajate töö konteksti, võime väita, et kutseõpetajate töö, olles reguleeritud mitmesuguste standarditega, eeldab kollegiaalset tegutsemist (Sirk et al., 2016).

Oma uurimuses oleme võtnud analüüsi aluseks Hoyle’i (1974) piiratud ja avaravaatelise professionaalsuse kontseptuaalse mudeli (vt tabel 1), paigutades selle tänapäeva ehk Hargreavesi järgi kollegiaalse professionalismi ajajärku. Lähtudes Hoyle’i mudelist, püstitame esimese hüpoteesi $\left(\mathrm{H}_{1}\right)$ : Eesti kutseõpetajad diferentseeruvad selle järgi, kuidas nad koostööd ja autonoomiat oma professionaalsuses tajuvad.

\section{Õpetajate professionaalsuse muutunud kontekst}

\section{Eesti kui siirderiigi kontekst ja kutsehariduspoliitilised suundumused}

Eesti kui postsotsialistliku riigi viimaste kümnendite reformid ning nendega kaasnenud haridusmuutused on olnud radikaalsed ja läbi põimunud tervet ühiskonda läbivatest muutustest. Eesti haridussüsteem on pidanud reageerima kahele paralleelselt toimunud muutusele, milleks on üleminek kommunistlikult režiimilt demokraatlikule ühiskonnakorraldusele ning iseseisva haridussüsteemi ülesehitamine. Samuti on Eesti hariduspoliitilist arengut mõjutanud juba 1990ndate lõpust neoliberalistlik poliitika (Loogma, Tafel-Viia, \& Ümarik, 2013). Globaalne haridusreformide liikumine GERM (Sahlberg, 2010) rõhutab koolide valikuvabadust, ettevõtlusprintsiipide ülekandmist haridusse ning koolide detsentraliseerimist, kuid neoliberalistliku hariduspoliitikaga kaasneb detsentraliseerimistendentsidele vastukaaluks standardiseerimine, samuti koolide aruandluskohustus. Haridussüsteemid ja õpetajad paiknevad seega kahe vastandliku suundumuse mõjuvallas: ühelt poolt üha kasvav standardiseerimine ning koolide ja õpetajate kohustus anda tulemuste kohta aru ning teisalt ootused toetada loovust ja innovaatilisust kui majandussüsteemide konkurentsivõime vedureid ( $i b i d$ ). Need globaalsed trendid avaldavad vastuolulisi nõudmisi õpetajate tööle ning tekitavad vajaduse mõtestada, kuidas haakuvad ühiskondlikud ootused ja õpetajate arusaamad oma professionaalsusest. 
Kutseharidusreform taasiseseisvunud Eestis on olnud pikaajaline ja süsteemne (Grootings, 2009), haarates kompleksseid muutusi alates óppekavade reformist kuni kutseõppeasutuste võrgustiku ümberkujundamiseni ning uute suhete loomiseni ettevõtete ja kutseõppeasutuste vahel (Ümarik, 2015). Kui nõukogudeaegne kutseharidus oli tsentraliseeritud ja tihedalt seotud plaanimajandusega, siis üleminekuaja koolide ja ettevõtete vahelised sidemed purunesid. Koos kutseharidussüsteemi üleminekuga koolipõhiseks muutusid kutsekoolide ja ettevõtete koostöö ning kutsehariduse kooskõlastamine majanduslike ja tööturu vajadustega (Loogma, 2010).

Ajavahemikku 1990ndate algusest kuni aastani 1996/1997 on nimetatud liberaalse kohanemise perioodiks, mida iseloomustas puudulik riiklik regulatsioon ning välisekspertide ja -doonorite oluline roll (Loogma, 2016). 1995. aastal alustati ELi PHARE programmi raames moodulõppekavade väljatöötamisega ning õppekava arendajate täienduskoolitustega (Rekkor, 2014). Kutsehariduse strateegiline riiklik planeerimine algas aga alles 1998. aastal, kui kinnitati kutsehariduse kontseptuaalsed lähtekohad ning võeti vastu kutseõppeasutuse seadus (Loogma, 2016). Kutseharidust hakati standardiseerima 2000. aastal kinnitatud kutseseadusega, millega sätestati kutsekvalifikatsiooninõuete väljatöötamise ning kutsekvalifikatsiooni tõendamise ja omistamise tingimused ja kord (Kutseseadus, 2000).

Alates 1990ndate lõpust hoogustus mitmete paralleelsete reformide rakendamine. Esiteks juurutati kutsekvalifikatsioonisüsteem, loodi kutsestandardid ja töötati välja riiklikud õppekavad. Teiseks kujundati ümber kutseõppeasutuste võrk ja koolid koondati regionaalseteks kutsehariduskeskusteks, sealhulgas ajakohastati infrastruktuur. Kolmandaks kehtestati uued kutseõppe liigid, nt eelkutseõpe, kutseõpe põhihariduseta õppuritele, kutseõpe lihtsustatud õppekava järgi (Loogma, 2004).

Alates 2000ndate algusest on Eesti kutsehariduspoliitika olnud tugevasti mõjutatud Euroopa Liidu kutsehariduspoliitilistest suundumustest, mille prioriteedid on kutseõppe kvaliteet, efektiivsus, atraktiivsus, asjakohasus ja läbipaistvus ning kutsekvalifikatsioonide võrreldavus. Eesti kutsehariduspoliitika keskmes on olnud kutsehariduse populariseerimine ja maine parandamine ühiskonnas laiemalt, samuti kutseõppe kvaliteedi vastavusse viimine tööturu vajadustega. Efektiivsemaks on muudetud kutseõppeasutuste ja ettevõtete koostööd, kasutusele on võetud paindlikumad õppevormid (sh töökohapõhine õpe, e-õpe), samuti on püütud arendada kutseõpetajate väljaõppe ja täienduskoolituse süsteemi (Eesti kutseharidussüsteemi arengukava, 2005, 2009; Loogma, 2016; The Copenhagen Declaration, 2002). 


\section{Kutseharidusreformiga kaasnenud muutuste mõju kutseõpetajate tööle}

Kutseõpetajaid nähakse võtmeisikutena kutseharidusvaldkonna probleemide lahendamisel ja muutuste elluviimisel (Cedefop, 2012). Reformidega kaasnenud haridusmuutused on mõjutanud oluliselt kutseõpetajate tööd ja nende ülesannetega seotud ootusi. Sageli tajuvad õpetajad paralleelselt rakendatud muutusi omavahel põimununa (Hargreaves \& Goodson, 2006), mistõttu on neil raske eristada, millisest konkreetsest reformipoliitikast uued nõudmised nende tööle tulenevad (Ümarik, 2015).

Varasemad uuringud (Rekkor et al., 2013; Ümarik, 2015) on näidanud, et kutseõpetajad kogevad muutusi erinevalt. Õpetajad võivad olla muutuste suhtes skeptilised või tõrjuvad, kuna paljud haridusreformid pole lähtunud kooli ja õpetajate vajadustest (Goodson, 2010; Goodson, Moore, \& Hargreaves, 2006; Müller, Norrie, Hernández, \& Goodson, 2010; Rekkor et al., 2013; Vähäsantanen \& Eteläpelto, 2009). Leitud on, et reformipoliitika, mis ei kaasa õpetajaid ega toeta õpetajate professionaalsust, ei ole edukas ega jätkusuutlik (Singh, 2011; Ümarik, Loogma, \& Tafel-Viia, 2014).

Kutseõpetajatel on kutseharidusreformide elluviimisel kaks rolli, olles reformidest tulenevate muutuste subjekt ja objekt. Muutuste subjektina on kutseõpetajad protsessides aktiivsed toimijad, kes muutusi kutsehariduses mõjutavad ja ellu viivad. Muutuste objektina peavad kutseõpetajad oma teadmisi ja oskusi pidevalt täiendama, et vastata nende tööle esitatavatele ootustele ja nõuetele (Singh, 2011).

Eesti kutseõpetajate tööd otseselt mõjutavad regulatiivsed muutused algasid 1995. aastal, kui kinnitati kutseõpetaja statuut, millega määrati esimest korda kindlaks nende töö sisu, esitati hariduslikud nõudmised ja võeti kasutusele termin kutseõpetaja. Sellega likvideeriti õpetajate senised eristuvad positsioonid (teooriaõpetaja ja õppemeister) ning kutseõpetaja pidi asuma õpetama nii teoreetilisi kui ka praktilisi erialaaineid. Lisaks tõi see kaasa pedagoogilise ja kõrghariduse nõude ning vajaduse täiendada end nii pedagoogiliselt kui ka õpetatavas valdkonnas, sh stažeerimise (Kutseõpetaja statuut, 1995). Viimastel kümnenditel on kutseõpetajate tööd üha enam standardiseeritud (Sirk et al., 2016) ja praegu hinnatakse nende kompetentsust uue kutseõpetaja kutsestandardi alusel, mis hakkas kehtima 2015. aastal.

Muutunud on ka kutseõpetajate igapäevane töö, mida regulatiivsed dokumendid ei pruugi kajastada. Üha enam kasutatakse õpilasi kaasavaid ja aktiveerivaid meetodeid ning õpetatakse praktiliste tegevuste kaudu. Õpetamisel kasutatavad e-keskkonnad on mitmekesistunud ja kutseõpetajad tajuvad survet arendada õpilaste digipädevusi, samas paljud õpilased ei tule sellega kaasa (Sirk et al., 2016). Kõige radikaalsemaid muutusi tajutakse õpilaskonnas, mis on 
diferentseerunud vanuse, hariduse ja kogemuste alusel, samuti on nähtavad erinevused motivatsioonis ning üldises õppimisoskuses ja võimekuses (Cort \& Rolls, 2010; Kats et al., 2010; Liivik \& Sirk, 2015; Sirk et al., 2016; Susimetsä, 2010). Murettekitavana kogetakse põhikooli lõpetanud õpilaste vähest õpimotivatsiooni, puudulikku funktsionaalset lugemisoskust ning suulise ja kirjaliku eneseväljenduse oskust, mistõttu lasub kutseõpetajatel kohustus arendada erialaõpingute kõrval ka elementaarseid põhioskusi (Sirk et al., 2016). Kutseõpetajad tunnetavad õppijatega seotud muutusi igapäevatööd ja toimetulekut raskendava asjaoluna (Cort \& Rolls, 2010; Liivik \& Sirk, 2015; Sirk et al., 2016).

Tööalane koostöö ja suhtlemine eri osalistega (ettevõtetega, kooli juhtkonnaga) on kasvanud. ELi kutseharidusprogrammid ja (rahvusvahelised) kutseharidusprojektid on olnud siinkohal olulisteks koolivälist ja rahvusvahelist koostööd laiendavateks teguriteks (Loogma, 2010). Samas pakub rahvusvahelistumine kutseõpetajatele võimalust end proovile panna, nõudes neilt rahvusvahelisel tasemel erialaseid teadmisi ja oskuseid, et valmistada õppureid ette kutsemeistrivõistlusteks. Ent kutseõpetajad tunnetavad oma ameti positsiooni ühiskonnas madalana, millele vastukaaluks püütakse esindada oma ametit positiivselt ja uhkelt (Sirk et al., 2016). Võib öelda, et õpetajad peavad õpetama viisil, milleks neid ei ole ette valmistatud (Hargreaves, 2006), ja muutuv olukord nõuab pidevat enesetäiendamist. Seejuures on üha olulisemaks muutunud koostöös õppimine - parimate erialaste ja pedagoogiliste praktikate ning õppematerjalide jagamine kolleegidega. Õpetajad ise mõistavad koostöös õppimise all laia ampluaaga tegevusi, näiteks inspiratsiooni saamist, kolleegide töö vaatlemist, erinevaid tegevusi ja arutelusid, mis on andnud uusi ideid oma õpetamispraktika muutmiseks (Sirk et al., 2016). Koostöös töötamist ja õppimist peetakse üheks efektiivseimaks muutustele reageerimise viisiks (Hargreaves, 2006). Haridusvaldkonnas on saanud koostöös töötamine universaalseks, kuna õpetajatele ja koolidele esitatavaid nõudmisi on võimalik täita vaid koostöös teiste osalistega (kolleegid, ettevõtted, sektororganisatsioonid jt) (Johns-Shepherd \& Gowing, 2007). Samas on parimate praktikate jagamine ja koostöös õppimine ka üks efektiivseimaid professionaalse enesearendamise vorme (Pickering, 2007). Varasemad uurimused on kinnitanud, et õpetajad (sh kutseõpetajad), kes kuuluvad eri koostöövõrgustikesse, võtavad haridusuuendusi kergemini omaks, kuna nad mõistavad sisuliselt paremini muudatuste eesmärke (Rekkor et al., 2013; Tafel-Viia et al., 2012; Vähäsantanen \& Eteläpelto, 2009; Ümarik \& Rekkor, 2013). Näiteks kogevad kutseõpetajad, kes osalesid PHARE projekti raames õppekavaarenduses ning on olnud aktiivsed riiklike õppekavade arendamisel ja asjaomaste võrgustike tegevustes, õppekavamuutusi positiivsemalt ning tunnetavad oma agentsust (agency) selles protsessis. Samas need, kes on jäänud võrgustikest eemale, on uute nõudmiste 
suhtes rahulolematumad, isegi mõneti pettunud õpetajatöös (Rekkor et al., 2013).

Eelnevast lähtudes püstitame kaks hüpoteesi:

- $\mathrm{H}_{2}$ : kutseõpetajad, kes teevad enam koostööd, on oma tööga rahulolevamad;

- $\mathrm{H}_{3}$ : kutseõpetajad, kes teevad enam koostööd, hindavad oma ameti staatust ühiskonnas kõrgemalt.

\section{Metoodika}

\section{Valim ja andmestik}

Praegune analüüs toetub institutsionaalse teadusteema „Õpetajate professionaalsuse ja professionalismi muutuv kontekst" raames korraldatud kutseõpetajate küsitluse andmetele. Küsitluse eesmärk oli uurida kutseõpetajate professionaalsust ja tööelu puudutavaid hoiakuid, praktikaid ning muutusi kutseõpetaja töös. Uuringusse kaasati kõik 37 Eesti kutseõppeasutust (kuid mitte rakenduskõrgkoole) ja osalemisnõusolek saadi 32 kutseõppeasutuselt (86,5\%). Kutseõpetajate kontaktid otsiti koolide veebilehtedelt ja välja saadeti 1685 e-küsimustikku, millest saadi tagasi 501 täidetud ankeeti. Vastanute jaotust võrreldi üldkogumi jaotusega vanuse, soo ning maakonna lõikes. Kuna maakonniti olid valimi ja üldkogumi vahelised kõikumised kõige suuremad, kaaluti andmed sellest jaotusest lähtudes. Maakondlikud jaotused peegeldavad muu hulgas eesti- ja venekeelsete õpetajate jaotumist, mida on oluline arvesse võtta. Vastanutest $65,5 \%$ olid naissoost kutseõpetajad. $73 \%$ kutseõpetajatest õpetas erialaaineid ja ülejäänud üldaineid. Vastanutest 79\% töötas linnapiirkonna kutsekoolides. $87 \%$ vastanutest täitis küsimustiku eesti keeles, ülejäänud vene keeles. Kutseõpetajate pedagoogiline töökogemus ulatus poolest aastast 48 aastani ning keskmine töökogemus oli 15 aastat $(S D=10,97)$. Vastanute hulgas oli kõige suurem kutseõpetajate osakaal (34\%) 55aastaste ja vanemate vanusegrupis, $31 \%$ vastanutest oli vanuses $45-54,21 \%$ 35-44 ja $14 \%$ alla 34 aasta. $58 \%$ vastanutest omas magistrikraadi, $23 \%$ bakalaureusekraadi või sellega võrdsustatud kvalifikatsiooni, ülejäänutel oli keskharidus või keskeriharidus. 60\% kutseõpetajatest töötas enam kui 700 õpilasega kutsekoolis.

Küsimustiku koostamise aluseks võtsime mitmed TALIS 2008 ja 2013 uuringu küsimuste plokid ja skaalad, mis võimaldavad teha võrdlust üldharidusõpetajatega ja rahvusvaheliselt. Küsimustikku lisasime valideeritud õpetajate autonoomia skaala TAS (Moomaw, 2005), mida kohandasime Eesti konteksti tarbeks. Lisaks sisaldas küsimustik kutseharidusmuutusi puudutavat osa, mis põhines 2014. aastal tehtud kvalitatiivse uuringu tulemustel (Sirk et al., 
2016). Veebipõhine küsitlus viidi läbi 2015. aasta lõpus nii eesti kui ka vene keeles.

Hoyle'i (1974) mudeli (vt tabel 1) alusel valisid kaks uurijat esmalt individuaalselt ja seejärel koos läbi arutades küsimustikust välja 26 algtunnust, mis sobisid piiratud ja avaravaatelise professionaalsuse mudeli kirjeldamiseks (vt tabel 2), ning katsid mudeli kuus esimest indikaatorit. Analüüs ei sisalda Hoyle'i mudeli kolme viimast indikaatorit järgmistel põhjustel:

- „Harv või sage erialakirjanduse lugemine“ - meie uuringus küsitletud kutseõpetajatest 95\% õppis sageli erialakirjandusest. Indikaatorit ei kaasatud edasisse analüüsi, kuna see ei erista kutseõpetajaid üksteisest;

- „Vähene haaratus oma professionaalsuse arendamisel, peamiselt praktikaga seotud kursused $v s$. laiem haaratus oma professionaalsuse arendamisel, sh teoreetilised kursused“ - mudeli analüüsimisel ja meie küsimustiku kõrvutamisel ei eristunud see indikaator eraldiseisvana tabelis 1 olevast kuuendast tunnusest, sest kutseõpetajatelt oodatakse pidevat enesetäiendamist ja eri osalistega tehtavat koostööd, mille kaudu ta õpib;

- „Õpetamist tajutakse intuitiivse $v$ s. ratsionaalse tegevusena“ - indikaatoriga haakuv tunnus puudus küsimustikust, kuid mudelis kirjeldatav indikaator seostub mudeli esimese indikaatoriga ehk teooria õppimise ja selle rakendamisega praktikas ning on seega kaudselt esindatud.

Küsimustiku koostamisel peeti silmas võrreldavust TALISe uuringuga, mistõttu kattuvate tunnuste puhul kasutati selles uuringus kasutusel olnud skaalasid (vt tabeli 2 esimest kahte tunnuste gruppi). Et tagada parem vastavus klasteranalüüsi eeldustele, kodeeriti esialgu 6-pallisel järjestusskaalal mõõdetud tunnused ümber 3-pallisele skaalale (1 - „mitte kunagi“, 2 - „aeg-ajalt“, 3 - „sageli“).

Kuna algtunnuseid oli suhteliselt palju (26) ja eelduse kohaselt olid nad seotud väiksema arvu latentsete muutujatega, siis seadsime eesmärgiks luua liittunnused. Esmalt katsetasime faktoranalüüsi, kuid ei saanud sellega sisuliselt ja teoreetiliselt põhjendatud mudelit, mistõttu koostasime liittunnused algtunnuste sisulisest sobivusest ja teoreetilisest haakuvusest lähtudes ning kasutasime nende usaldusväärsuse kontrollimiseks Cronbachi alfat (vt tabel 2). Algtunnuste sisuanalüüsi tulemusena eristus üheksa latentset muutujat, mille alusel koostasime seitse liittunnust, kusjuures mudelisse jäid eraldiseisvatena ka kaks algtunnust, kuna need ei haakunud teiste algtunnustega, olles samas Hoyle'i mudeli seisukohast olulised. 
Tabel 2. Algtunnuste koondamine liittunnusteks

\begin{tabular}{|c|c|}
\hline Algtunnused & Liittunnus \\
\hline $\begin{array}{l}\text { - Vahetate kolleegidega õppemetoodilisi materjale ja eriala- } \\
\text { seid õppematerjale } \\
\text { - Osalete koostööl põhinevas professionaalses enesearen- } \\
\text { duses (parimate praktikate jagamises kolleegidega) } \\
\text { - } \\
\text { - } \\
\text { - Oülastate kolleegide tunde ning annate neile tagasisidet } \\
\text { projektid, ooolisisesed ja koolivälised võistlused) }\end{array}$ & $\begin{array}{l}\text { Professionaalne koostöö } \\
\text { ja enesearendamine } \\
\text { koolis } \\
\text { Cronbachi } a=0,71\end{array}$ \\
\hline $\begin{array}{l}\text { - Osalete kooli õppekava või selle mõne osa arendamises } \\
\text { (mooduli rakenduskava) } \\
\text { - Teete koostööd teiste selle kooli õpetajatega tagamaks } \\
\text { teemade lõimimine } \\
\text { - Teete koostööd teiste selle kooli õpetajatega tagamaks } \\
\text { õpilaste hindamine ühtsete kriteeriumite alusel }\end{array}$ & $\begin{array}{l}\text { Koostööl põhinev } \\
\text { õppekavaarendus ja } \\
\text { õpetamine koolis } \\
\text { Cronbachi } a=0,63\end{array}$ \\
\hline $\begin{array}{l}\text { - Õpetamisel lähtun omaenda põhimõtetest ja arusaamadest } \\
\text { - Ma otsustan ise, mida oma tunnis õpetada } \\
\text { - Materjalid, mida tunnis kasutada, valin põhiosas ise } \\
\text { - Ma saan õpetamisel olla loominguline } \\
\text { - Ma saan ise valida, milliseid õppemeetodeid oma tunnis } \\
\quad \text { kasutada }\end{array}$ & $\begin{array}{l}\text { Autonoomia säilitamine } \\
\text { õppetöö korraldamisel } \\
\text { Cronbachi } a=0,84\end{array}$ \\
\hline $\begin{array}{l}\text { Uusi teadmisi ja ideid oma töö jaoks saadakse: } \\
\text { - } \text { agentuuridest, nagu Innove, Kutsekoda } \\
\text { - valdkonna erialaliitudest ja kutseorganisatsioonidest } \\
\text { - } \quad \text { õpetajate võrgustikest }\end{array}$ & $\begin{array}{l}\text { Osalemine ja õppimine } \\
\text { koolivälistes võrgustikes } \\
\text { Cronbachi } a=0,64\end{array}$ \\
\hline $\begin{array}{l}\text { Uusi teadmisi ja ideid oma töö jaoks saadakse: } \\
\text { - } \quad \text { vaatluskülastustel ja stažeerimisel ettevõtetes } \\
\text { - } \quad \text { kutsemeistrivõistlustelt } \\
\text { - } \quad \text { vaatluskülastustelt teistesse kutseõppeasutustesse }\end{array}$ & $\begin{array}{l}\text { Kooliväline profession- } \\
\text { aalne enesearendus ja } \\
\text { arendustöö } \\
\text { Cronbachi } a=0,72\end{array}$ \\
\hline $\begin{array}{l}\text { Uusi teadmisi ja ideid oma töö jaoks saadakse: } \\
\text { - } \quad \text { Eesti-sisestest koostööprojektidest } \\
\text { - } \text { rahvusvahelistest koostööprojektidest }\end{array}$ & $\begin{array}{l}\text { Osalemine ja õppimine } \\
\text { projektitöös } \\
\text { Cronbachi } a=0,76\end{array}$ \\
\hline $\begin{array}{l}\text { Uusi teadmisi ja ideid oma töö jaoks saadakse: } \\
\text { - } \quad \text { kvalifikatsiooniprogrammist (nt kraadiõppeprogramm) } \\
\text { - } \quad \text { uuringute korraldamisest } \\
\text { - } \text { pedagoogilistest koolitustest (õppimine) } \\
\text { - } \quad \text { hariduskonverentsidelt, seminaridelt, töötubadest }\end{array}$ & $\begin{array}{l}\text { Osalemine ja õppimine } \\
\text { formaalsetel koolitustel } \\
\text { ning teadustööle tugi- } \\
\text { nevas koostöös } \\
\text { Cronbachi } a=0,62\end{array}$ \\
\hline Suurenenud võimalus koolijuhtimises kaasa rääkida & \\
\hline
\end{tabular}




\section{Andmeanalüüsi meetodid}

Et vastata artiklis formuleeritud kolmele hüpoteesile, rakendasime järgmisi andmeanalüüsi meetodeid, kasutades statistikapaketti SPSS 22.0:

- analüüsi esimeses etapis klassifitseerisime $k$-keskmiste klasteranalüüsi abil kutseõpetajad nende koostöö ulatuse alusel. Saadud klastreid võrdlesime seejärel kõikide mudelis olevate tunnuste kaupa (vt tabel 2), kasutades ANOVA ja Bonferroni paariviisiliste võrdluste testi;

- teises etapis võrdlesime klastreid demograafiliste tunnuste alusel (vanus, kooli asukoht (linna- või maakool), õpilaste arv, vastajate haridustase, pedagoogiline töökogemus, sugu, õpetatav valdkond, keel), milleks kasutasime risttabelit. Erinevuste statistilist olulisust kontrollisime hii-ruut-testiga;

- kolmandas etapis võrdlesime aritmeetiliste keskmistega eri klastritesse kuuluvate kutseõpetajate hinnanguid kutseõpetaja ametile ja staatusele. Erinevuste statistilist olulisust kontrollisime dispersioonanalüüsiga (ANOVA) ja aritmeetiliste keskmiste võrdlemisel kasutasime Bonferroni testi.

ANOVA testi puhul on kõik võrdlused tehtud kolme grupi vahel ja seega on vabadusastmete arv $(d f)$ läbivalt 2 .

\section{Tulemused}

\section{Kutseõpetajate klastrid}

Analüüsi tulemusena osutus parimaks lahendiks kolme klastriga mudel, mille puhul eristusid klastrid statistiliselt olulisel määral kõigi klastrite moodustamise aluseks olnud üheksa tunnuse poolest. Saadud klastrid nimetasime järgmiselt: „ulatuslikult võrgustunud professionaalid“, „omaette hoidvad professionaalid“ ja „koolikesksed professionaalid“ (vt tabel 3).

Esimesse klastrisse „ulatuslikult võrgustunud professionaalid“ kuulub 27\% vastanud kutseõpetajatest. Selle grupi kutseõpetajad osalevad kõige enam koostööl põhinevas õppekavaarenduses ja õpetamistegevustes. Nad teevad professionaalset koostööd aeg-ajalt, kuid sagedamini kui teise või kolmandasse klastrisse kuuluvad kutseõpetajad. Peale koolisisese koostöö ollakse ka kõige enam koolivälisesse koostöösse haaratud, näiteks õpitakse sageli koolivälistes võrgustikes ja projektides, arendatakse ennast tööalaselt ning osaletakse arendustöös. Ka formaalsetel koolitustel ja teadustööle tuginevas koostöös osalevad ja õpivad nad sagedamini kui teistesse klastritesse kuuluvad õpetajad. Mitmekesisest koostööst hoolimata kogetakse endiselt autonoomiat õppetöö korraldamisel. Võrreldes teistesse klastritesse kuuluvate õpetajatega tajutakse kõige enam oma rolli koolijuhtimises ning tuntakse, et mõjutatakse hariduse kaudu õpilaste elu. 
Tabel 3. Kutseõpetajate klastrid

\begin{tabular}{|c|c|c|c|c|c|c|}
\hline $\begin{array}{c}\text { Tunnused } \\
\text { klastrite loomisel }\end{array}$ & $M / S D$ & $\begin{array}{c}\text { I klaster } \\
n=133(27 \%) \\
\text { Ulatuslikult } \\
\text { võrgustunud } \\
\text { professionaalid }\end{array}$ & $\begin{array}{c}\text { Il klaster } \\
n=141(28 \%) \\
\text { Omaette } \\
\text { hoidvad pro- } \\
\text { fessionaalid }\end{array}$ & $\begin{array}{c}\text { III klaster } \\
n=227(45 \%) \\
\text { Koolikesksed } \\
\text { professio- } \\
\text { naalid }\end{array}$ & $F$ & $p$ \\
\hline $\begin{array}{l}\text { Professionaalne } \\
\text { koostöö ja } \\
\text { enesearendamine } \\
\text { koolis }\end{array}$ & $\begin{array}{l}M \\
S D\end{array}$ & $\begin{array}{c}2,11^{\text {(II ja III) }} \\
0,48\end{array}$ & $\begin{array}{c}1,47^{(\text {I j a III) }} \\
0,39\end{array}$ & $\begin{array}{c}1,87^{\text {(1ja ll) }} \\
0,46\end{array}$ & 72,27 & 0,00 \\
\hline $\begin{array}{l}\text { Koostööl põhinev } \\
\text { õppekavaarendus } \\
\text { ja õpetamine } \\
\text { koolis }\end{array}$ & $\begin{array}{l}M \\
S D\end{array}$ & $\begin{array}{c}2,56^{(\text {IIj a III) }} \\
0,46\end{array}$ & $\begin{array}{c}1,85^{(\text {Ij a III) }} \\
0,51\end{array}$ & $\begin{array}{c}2,32^{(\text {j a ll) }} \\
0,52\end{array}$ & 73,11 & 0,00 \\
\hline $\begin{array}{l}\text { Autonoomia } \\
\text { säilitamine õppe- } \\
\text { töö korraldamisel }\end{array}$ & $\begin{array}{l}M \\
S D\end{array}$ & $\begin{array}{c}3,55^{(I I I)} \\
0,41\end{array}$ & $\begin{array}{c}3,55^{(I I I)} \\
0,42\end{array}$ & $\begin{array}{c}3,30^{\text {(I j ll) }} \\
0,47\end{array}$ & 19,54 & 0,00 \\
\hline $\begin{array}{l}\text { Osalemine ja } \\
\text { õppimine kooli- } \\
\text { välistes } \\
\text { võrgustikes }\end{array}$ & $\begin{array}{l}M \\
S D\end{array}$ & $\begin{array}{c}3,15^{\text {(II ja III) }} \\
0,45\end{array}$ & $\begin{array}{c}1,81^{(\text {I j a III) }} \\
0,48\end{array}$ & $\begin{array}{c}2,40^{\text {(Ij a ll) }} \\
0,46\end{array}$ & 286,50 & 0,00 \\
\hline $\begin{array}{l}\text { Kooliväline } \\
\text { professionaalne } \\
\text { enesearendus ja } \\
\text { arendustöö }\end{array}$ & $\begin{array}{l}M \\
S D\end{array}$ & $\begin{array}{c}3,02^{\text {(II ja III) }} \\
0,58\end{array}$ & $\begin{array}{c}1,61^{(\text {I j a III) }} \\
0,48\end{array}$ & $\begin{array}{c}2,32^{(\text {j a ll) }} \\
0,49\end{array}$ & 257,65 & 0,00 \\
\hline $\begin{array}{l}\text { Osalemine ja } \\
\text { õppimine } \\
\text { projektitöös }\end{array}$ & $\begin{array}{l}M \\
S D\end{array}$ & $\begin{array}{c}2,98^{\text {(II ja III) }} \\
0,67\end{array}$ & $\begin{array}{c}1,24^{(\text {Ij a III) }} \\
0,39\end{array}$ & $\begin{array}{c}2,20^{\text {(Ij a II) }} \\
0,51\end{array}$ & 366,99 & 0,00 \\
\hline $\begin{array}{l}\text { Osalemine } \\
\text { ja õppimine } \\
\text { formaalsetel } \\
\text { koolitustel ning } \\
\text { teadustööle tugi- } \\
\text { nevas koostöös }\end{array}$ & $\begin{array}{l}M \\
S D\end{array}$ & $\begin{array}{c}2,66^{(I I ~ j a ~ I I I)} \\
0,49\end{array}$ & $\begin{array}{c}1,81^{(\text {l ja III) }} \\
0,46\end{array}$ & $\begin{array}{c}2,22^{(\text {l ja II) }} \\
0,41\end{array}$ & 123,24 & 0,00 \\
\hline $\begin{array}{l}\text { Suurenenud } \\
\text { võimalus kooli- } \\
\text { juhtimises kaasa } \\
\text { rääkida }\end{array}$ & $\begin{array}{l}M \\
S D\end{array}$ & $\begin{array}{c}3,42^{(\text {I j a III) }} \\
0,60\end{array}$ & $\begin{array}{c}2,59^{(\text {Ij a III) }} \\
0,80\end{array}$ & $\begin{array}{c}2,92^{(\text {j a ll })} \\
0,65\end{array}$ & 51,43 & 0,00 \\
\hline $\begin{array}{l}\text { Tunnen, et } \\
\text { mõjutan hariduse } \\
\text { kaudu oluliselt } \\
\text { oma õpilaste elu }\end{array}$ & $\begin{array}{l}M \\
S D\end{array}$ & $\begin{array}{c}3,52^{(\text {(I ja III) }} \\
0,53\end{array}$ & $\begin{array}{l}3,07^{(1)} \\
0,71\end{array}$ & $\begin{array}{l}2,99^{(1)} \\
0,60\end{array}$ & 32,28 & 0,00 \\
\hline
\end{tabular}

Märkused. Kaks esimest klasterdamise aluseks olnud tunnust on kolmepalliskaalal, teised tunnused neljapalliskaalal. Klastrite keskväärtuste juures on indikatiivsena märgitud, millis(t)est teis(t)est klastri(te)st nad erinevad statistiliselt olulisel määral $(p<0,05)$. 
Teise klastrisse kuuluvad kutseõpetajad (28\%) teevad võrreldes teiste klastrite õpetajatega kõige vähem koostööd, mistõttu nimetame seda gruppi kui „omaette hoidvad professionaalid“. Siia klastrisse kuuluvad professionaalid tunnevad samavõrd autonoomiat õppetöö korraldamisel kui ulatuslikult võrgustunud professionaalid, mistõttu selle tunnuse alusel need klastrid omavahel ei eristunud $(p=1,00)$. Omaette hoidvad professionaalid üldiselt ei tee koolivälist koostööd ega ole haaratud koolivälistesse õpivõrgustikesse. Kuigi koostööst ollakse irdunud, hinnatakse oma enesetõhusust sarnaselt kolmanda klastri kutseõpetajatega. Võrreldes teiste klastritega nähakse oma rolli koolijuhtimises veidi tagasihoidlikumana, kuid seda peetakse siiski oluliseks.

Ligi pool uuringus osalenud kutseõpetajatest (45\%) kuulub kolmandasse klastrisse. Kuna nende koostöö haarab eelkõige koolisisest koostööd, siis nimetame seda gruppi kui „koolikesksed professionaalid“. Koolisisese koostöö sageduse poolest paigutub see õpetajate klaster kahe eelmise klastri vahele. Võrreldes esimese klastri õpetajatega teevad selle klastri kutseõpetajad pisut harvem koolisisest professionaalset koostööd ja arendavad end vähem tööalaselt, samuti on nende puhul väiksem osakaal koostöisel õppekavaarendusel ja koosõpetamisel, kuid nad edestavad nende tegevuste sageduse poolest teise klastrisse kuuluvaid õpetajaid. Samas peavad nad oluliseks oma rolli koolijuhtimises. Nad tunnevad pisut vähem autonoomiat õppetöö korraldamisel, kuid enesetõhususe näitaja poolest sarnanetakse teise klastri kutseõpetajatega ja ei eristuta neist statistiliselt olulisel määral $(p=0,62)$. Võib järeldada, et mõlema klastri kutseõpetajad tunnevad koostöö ulatusest olenemata, et nad mõjutavad õpilaste elu hariduse kaudu.

Kuigi klasteranalüüsi puhul ei ole empiiriliste üldistuste tegemine klastritevaheliste erinevuste statistilise olulisuse põhjal matemaatiliselt põhjendatud, võib lähtudes asjaolust, et valim katab suhteliselt suure osa üldkogumist, järeldada, et esimene hüpotees leidis kinnitust ehk kutseõpetajad diferentseeruvad vastavalt sellele, kuidas nad koostööd ja autonoomiat oma professionaalsuses tajuvad.

\section{Klastrite võrdlemine demograafiliste tunnuste alusel}

Järgnevalt võrdlesime kutseõpetajate klastreid sotsiaal-demograafiliste tunnuste alusel. Selgus, et klastrid ei eristu statistiliselt olulisel määral vanuse, kooli asukoha (linna- või maakool), õpilaste arvu, vastajate haridustaseme ja pedagoogilise töökogemuse poolest. Küll aga ilmnesid statistilised erinevused soo, õpetatava valdkonna ning keele puhul. 
Sotsiaal-demograafiliste tunnuste põhjal (vt tabel 4) selgus, et meessoost kutseõpetajad teevad vähem mitmekesist koostööd võrreldes naissoost kutseõpetajatega ja suurem osa meesõpetajaid kuulub omaette hoidvate professionaalide klastrisse $(p=0,01)$. Ulatuslikult võrgustunud professionaalide klastrisse kuulub enam erialaaineid õpetavaid kutseõpetajaid, seevastu omaette hoidvate professionaalide klastrisse rohkem üldainete õpetajaid. Võib järeldada, et kutseõpetajate koostöö ulatus sõltub õpetamise valdkonnast $(p=0,00)$.

Tabel 4. Klastrite kirjeldamine sotsiaal-demograafiliste tunnuste alusel

\begin{tabular}{l|l|c|c|c|c|c|c}
\hline \multicolumn{2}{c|}{$\begin{array}{c}\text { Klastreid kirjeldavad } \\
\text { tunnused }\end{array}$} & $\begin{array}{c}\text { I klaster } \\
n=133\end{array}$ & $\begin{array}{c}\text { II klaster } \\
n=141\end{array}$ & $\begin{array}{c}\text { II klaster } \\
n=227\end{array}$ & $\begin{array}{c}\text { Kokku } \\
100 \%\end{array}$ & $X^{2}$ & $p$ \\
\hline \multirow{2}{*}{ Sugu } & Naine & $28 \%$ & $24 \%$ & $48 \%$ & $100 \%$ & 9,21 & 0,01 \\
\cline { 2 - 6 } & Mees & $23 \%$ & $37 \%$ & $40 \%$ & $100 \%$ & & \\
\hline \multirow{2}{*}{$\begin{array}{l}\text { Õpetamise } \\
\text { valdkond }\end{array}$} & Üldained & $13 \%$ & $40 \%$ & $48 \%$ & $100 \%$ & 22,99 & 0,00 \\
\cline { 2 - 6 } & Erialaained & $32 \%$ & $24 \%$ & $44 \%$ & $100 \%$ & & \\
\hline \multirow{2}{*}{ Keel } & Eesti keel & $29 \%$ & $26 \%$ & $45 \%$ & $100 \%$ & 15,32 & 0,00 \\
\cline { 2 - 6 } & Vene keel & $10 \%$ & $45 \%$ & $45 \%$ & $100 \%$ & & \\
\hline
\end{tabular}

Esmase kõnekeele järgi eesti keelt kõnelevad kutseõpetajad teevad enam ulatuslikumat ja koolisisest koostööd. Vene keelt kõnelevad kutseõpetajad kuuluvad võrdselt omaette hoidvate ja koolikesksete professionaalide klastritesse. Võib järeldada, et eesti keelt esmase kõnekeelena rääkivad kutseõpetajad on rohkem koostöösse haaratud kui vene keelt kõnelevad õpetajad $(p=0,00)$.

\section{Klastrite võrdlemine kutseõpetaja ametile ja staatusele antavate hinnangute alusel}

Tulemustest selgub, et ulatuslikult võrgustunud professionaalid hindavad tööga rahulolu ja ameti kindlust kõrgemalt võrreldes teistesse klastritesse kuuluvate kutseõpetajatega (vt tabel 5). Seega võib näha, et mida rohkem koostööd tehakse, seda positiivsem on hoiak oma töötulemuste suhtes ning ühtlasi ollakse kindlamad ka oma ameti valikus. Teiseks on ulatuslikult võrgustunud professionaalid enam rahul oma töö ja töötulemustega kutsekoolis. Seda kinnitas ka Bonferroni test, mis näitas, et ulatuslikult võrgustunud professionaalide klaster eristub kindlalt teistest klastritest. Seega, meie teine hüpotees leidis kinnitust ehk kutseõpetajad, kes teevad enam koostööd, on oma tööga rahulolevamad. 
Tabel 5. Kutseõpetaja ametile ja tööle antavad hinnangud klastrite kaupa

\begin{tabular}{|c|c|c|c|c|c|c|}
\hline Tunnus ankeedist & $M / S D$ & $\begin{array}{l}\text { I klaster } \\
n=133\end{array}$ & $\begin{array}{c}\text { II klaster } \\
n=141\end{array}$ & $\begin{array}{c}\text { III klaster } \\
n=227\end{array}$ & $F$ & $p$ \\
\hline \multirow{2}{*}{$\begin{array}{l}\text { Kui ma saaksin uuesti } \\
\text { otsustada, valiksin ikkagi } \\
\text { kutseõpetaja töö/ameti }\end{array}$} & $M$ & $3,09^{(I I j \text { j IIII)* }}$ & $2,78^{(1)^{*}}$ & $2,86^{(1)^{*}}$ & \multirow[t]{2}{*}{6,26} & \multirow[t]{2}{*}{0,00} \\
\hline & $S D$ & 0,73 & 0,85 & 0,74 & & \\
\hline \multirow{2}{*}{$\begin{array}{l}\text { Olen rahul oma } \\
\text { töötulemustega selles } \\
\text { kutseõppeasutuses }\end{array}$} & $M$ & $3,22^{(I \mathrm{Ij} \text { a III)* }}$ & $2,97^{(1)^{*}}$ & $3,08^{(1)^{*}}$ & \multirow[t]{2}{*}{8,67} & \multirow[t]{2}{*}{0,00} \\
\hline & $S D$ & 0,56 & 0,53 & 0,45 & & \\
\hline \multirow[t]{2}{*}{ Üldiselt olen oma tööga rahul } & $M$ & $3,27^{(\text {IIj a III)* }}$ & $3,03^{(1)^{*}}$ & $3,12^{(1)^{*}}$ & \multirow[t]{2}{*}{6,03} & \multirow[t]{2}{*}{0,00} \\
\hline & $S D$ & 0,59 & 0,65 & 0,50 & & \\
\hline \multirow{2}{*}{$\begin{array}{l}\text { Leian, et kutseõpetaja amet } \\
\text { on ühiskonnas väärtustatud }\end{array}$} & $M$ & 2,21 & 2,01 & 2,16 & \multirow[t]{2}{*}{2,45} & \multirow[t]{2}{*}{0,09} \\
\hline & $S D$ & 0,90 & 0,82 & 0,71 & & \\
\hline
\end{tabular}

Märkused. Hinnangud anti skaalal 1 („üldse ei nõustu“) kuni 4 („nõustun täiesti“). * - statistiline erinevus klastrite vahel Bonferroni testi alusel $(p<0,05)$.

Lisaks hindavad ulatuslikult võrgustunud professionaalid pisut kõrgemalt ka kutseõpetajate staatust ühiskonnas (vt tabel 5), kuid sellest hoolimata ei eristu hinnang oma kutse staatusele teiste klastrite kutseõpetajate omast statistiliselt olulisel määral $(p=0,09)$. Sellest võib järeldada, et kutseõpetaja amet ühiskonnas ei ole õpetajate hinnangul väärtustatud. Seega, kolmas hüpotees ei leidnud praeguse valimi põhjal piisavat kinnitust, kuid valimi tulemused annavad alust järgmistes uuringutes seda hüpoteesi uuesti kontrollida.

\section{Järeldused}

Uurimuse eesmärk oli mõista kutseõpetajate professionaalsust kollegiaalse professionalismi ajajärgul. Kutseõpetajate koostöö osutus oluliseks professionaalsust määravaks teguriks. See tuleneb Eesti kutsehariduses toimunud muutustest, mida on toetatud mitmesuguste mehhanismidega (sh rahastamine) ning mis on viinud kutseõpetaja kutse kollegiaalse professionalismi ajajärku. Samas on see üleminek põhjustanud kutseõpetajaskonna diferentseerumise koostöö ulatuse alusel. Nimelt eristus klasteranalüüsi tulemusena kolm kutseõpetajate klastrit ning see tulemus kinnitab meie esimest hüpoteesi, et Eesti kutseõpetajad on diferentseerunud oma professionaalsuse alusel.

Analüüsi tulemusena loodud klastrite puhul ei saa väita, et omaette hoidvaid professionaale oleks võimalik samastada Hoyle'i mudelis (1974) toodud „piiratud professionaalidega“. Vähesest koostööst hoolimata tunnevad need 
õpetajad siiski, et mõjutavad oma tegevusega õpilaste elu ja tähtsustavad teatud määral koolijuhtimises kaasarääkimist. Niisiis mõistavad koostööst eemale jäänud kutseõpetajad oma professionaalset tööd laiemalt kui vaid klassiruumi tegevusena, kuigi seda ei tehta kollegiaalselt. Seega, meie analüüs ei näidanud piiratud professionaalide rühma olemasolu kutseõpetajate hulgas nii, nagu see on Hoyle'i (1974) mudelis esitatud. Ka Hoyle ise on oma hilisemas artiklis (2008) rõhutanud, et muutused on tinginud õpetajate laiaulatuslikuma koostöö ning vähendanud piiratud professionaalide rühma esinemise võimalikkust.

Meie teine hüpotees - kutseõpetajad, kes teevad enam koostööd (I klaster), on oma tööga rahulolevamad - leidis kinnitust ja ühtib ka varasemate uurimistulemustega (Rekkor et al., 2013; Tafel-Viia et al., 2012; Ümarik \& Rekkor, 2013). Tulemused kinnitavad, et laiem koostöö kutseõpetajate seas on oluline, kuna see soodustab positiivsemat suhtumist oma töösse ja selle tulemustesse ning üleüldist rahulolu oma ametiga. Muu hulgas toetab koostöös tegutsemine muutuste mõtestamist (Spillane et al., 2002) ja omaksvõttu. Kui pöörata tähelepanu klastrite osakaaludele, siis võib näha, et ulatuslikult võrgustunud professionaale on kutseõpetajate seas pea sama palju kui omaette hoidvaid professionaale ja enamik õpetajaid on haaratud koolisisesesse koostöösse. Seetõttu on oluline mõelda, kuidas koostööst eemaldunud kutseõpetajaid kaasata rohkem erinevatesse koolisisestesse ja -välistesse võrgustikesse, mis toetaks neid muutustega toimetulekul ning kujundaks positiivsemaid hinnanguid oma ametile ja töötulemustele.

Meie tulemused viitavad, et vene kõnekeelega kutseõpetajad on pigem koostööst eemaldunud, piirduvad koolisisese koostööga ja on vähem haaratud koolivälistesse õpivõrgustikesse. Ka meie varasemast uuringust (Ümarik \& Rekkor, 2013) on ilmnenud, et vene keelt kõnelevate õpetajate hulgas on enam kibestunud ja omaette hoidvaid õpetajaid, kes tunnevad koolisisest survet muutuste tegemiseks, kuid vähe tuge muutustega kohanemisel. Ka on riiklike õppekavade arendamiseks loodud valdkondlikud võrgustikud eestikeelsed, millest venekeelsed õpetajad on valdavalt eemale jäänud. Kuna oleks liiga optimistlik eeldada, et õpetajad ise otsiksid võimalusi teha avaramat koostööd (Hoyle, 2008), vajaks täiendavat uurimist, kuidas venekeelsed õpetajad kogevad oma professionaalsust ja nõudmisi oma töörollile ning kuidas saaks venekeelsete õpetajate kohanemist muutustega ja võrgustumist toetada. Lisaks ilmnes meie uurimusest, et ka meessoost ja üldainete kutseõpetajad kuuluvad enamjaolt omaette hoidvate professionaalide klastrisse, mis viitab, et ka neile tuleks pöörata enam tähelepanu.

Koostöös (sh võrgustikes) tegutsemine võimaldab võtta õpetajal vastutust hariduse arendamise eest oma organisatsioonis või laiemalt ühiskonnas (JohnsShepherd \& Gowing, 2007). Kuna meie tulemustest selgus, et kõik grupid 
pidasid suuremal või vähemal määral oluliseks suurenenud võimalust kaasa rääkida koolijuhtimist puudutavates küsimustes, võib järeldada, et valmisolek koostöö laienemiseks on olemas, kuid seda tuleks toetada ning ühisest koostööst eemaldunud õpetajaid tuleks kaasata eri võrgustikesse, et neil tekiks positiivne hoiak ja arusaam koostöö vajalikkusest (Pachler, 2007).

Kuna eri klastritesse kuuluvate kutseõpetajate hinnangud kutseõpetaja kutse staatusele ühiskonnas ei erine statistiliselt olulisel määral, siis meie kolmas hüpotees ei leidnud kinnitust ning hinnang oma kutseala staatusele ei ole oluliselt seotud professionaalsusega. Teisisõnu, koostöö kui õpetajate nn uut professionaalsust määratlev põhitegur ei ole meie uuringu tulemuste põhjal seotud arusaamaga professiooni staatusest ühiskonnas.

Hoyle'i mudel võimaldas avada autonoomia ja koostöö olemust kutseõpetajate töös ning mõtestada autonoomia ja koostöö rolli kutseõpetajate professionaalsuses kollegiaalse professionalismi ajajärgul. Nagu tulemused näitavad, ei vähenda laienenud kollegiaalsus ja koostöö kutseõpetajate autonoomiat. Seega, autonoomia tänapäeva mõistes ei tähenda isoleeritud tegutsemist klassiruumis või omaette nokitsemist, vaid sellele ajajärgule on omane uus arusaam autonoomiast: tähtis on koostöine otsuste tegemine (Evetts, 2002; Pearson \& Moomaw, 2006). Võib järeldada, et õpetajad hindavad autonoomiat oma professionaalsuses oluliseks ja vastupidi Hoyle'i mudelile võib väita, et autonoomia ja koostöö ei ole vastanduvad dimensioonid kutseõpetajate professionaalsuses. Kuigi koostöös otsustamine on kutseõpetajate autonoomia osa, on ligi veerand kutseõpetajatest siiski koostööst eemaldunud. Seetõttu kerkib küsimus, mida kutseõpetajad autonoomia all tegelikult mõistavad. Kuna õpetajad on oma tööpraktikas piiratud mitmesugustest standarditest, normidest ja õigusaktidest, siis kas oleks tõepoolest adekvaatsem rääkida autonoomia asemel valikuvabadusest otsustamisel, nagu Evetts (2002) välja pakub? Artiklis kasutatud kvantitatiivne uurimisviis ei võimalda mõista, kuidas kutseõpetajad autonoomiat oma töös mõtestavad ning millist rolli see nende professionaalsuses omab. Neid aspekte saame avada oma edasise narratiivuuringu raames, mille korral teeme eri klastritesse kuuluvate kutseõpetajatega narratiivsed tööeluintervjuud.

Teadvustame, et küsitlusuuring võis seada teatavad piirangud tulemuste üldistatavusele. Kuigi vanuse alusel ei ilmnenud suuri erinevusi valimi ja üldkogumi võrdluses, võib arvata, et veebiküsitlusele, eelkõige staažikama õpetajaskonna puhul, on enam motiveeritud vastama need õpetajad, kes tunnevad end IKT-vahendite kasutamisel pädevamalt. Samuti võime eeldada, et koostöisemad õpetajad on ka küsitlustele vastamisel aktiivsemad kui koostööst eemaldunud õpetajad. 


\section{Tänusõnad}

Täname kõiki kutseõpetajaid, kes nõustusid küsitluses osalema.

Artikkel on valminud IUT18-2 teadusteema „Õpetajate professionaalsuse ja professionalismi muutuv kontekst“ (01.01.2014-31.12.2019) raames, mida rahastab sihtasutus Eesti Teadusagentuur.

\section{Kasutatud kirjandus}

Antikainen, A., Rinne, R., \& Koski, L. (2009). Haridussotsioloogia. Tallinn: Tallinna Ülikool.

Brouwer, P., Brekelmans, M., Nieuwenhuis, L., \& Simons, R.-J. (2012). Communities of practice in the school workplace. Journal of Educational Administration, 50(3), 346-364. https://doi.org/10.1108/09578231211223347

Cedefop (2012). Trends in VET policy in Europe 2010-12: Progress towards the Bruges communiqué. Luxembourg: Publications Office of the European Union. Retrieved from http://www.cedefop.europa.eu/en/publications/20814.aspx.

Clow, R. (2001). Further education teachers' constructions of professionalism. Journal of Vocational Education and Training, 53(3), 407-420.

https://doi.org/10.1080/13636820100200166

Cort, P. (2011). Trends in VET teaching and training: Teachers' perceptions of change and implications for teaching practice in Denmark. In S. R. Kirpal (Ed.), National pathways and European dimensions of trainers' professional development (pp. 45-62). Frankfurt am Main: Peter Lang.

Cort, P., \& Rolls, S. (2010). IVET teachers' perceptions of change and their implications for teaching. In S. Kirpal (Ed.), Changing roles and competences of VET teachers and trainers. Final Report / Vol. II: National summaries of interview results (pp. 59-69). Germany: University of Bremen.

Daly, A. J., Nienke, M. M., Bolivar, J. M., \& Burke, P. (2010). Relationships in reform: The role of teachers' social network. Journal of Educational Administration, 48(3), 359-391. https://doi.org/10.1108/09578231011041062

Eesti kutseharidussüsteemi arengukava aastateks 2005-2008 (2005). Haridus- ja Teadusministeerium.

Eesti kutseharidussüsteemi arengukava 2009-2013 (2009). Tartu: Haridus- ja Teadusministeerium. Külastatud aadressil https://www.hm.ee/sites/default/files/kutseharidusysteemi_arengukava_2009_2013.pdf.

Evans, L. (2008). Professionalism, professionality and the development of education professionals. British Journal of Educational Studies, 56(1), 20-38. https://doi.org/10.1111/j.1467-8527.2007.00392.x

Evetts, J. (2002). New directions in state and international professional occupations: Discretionary decision-making and acquired regulation. Work, Employment and Society, 16(2), 341-353. https://doi.org/10.1177/095001702400426875

Evetts, J. (2009). The management of professionalism. In S. Gewirtz, P. Mahony, I. Hextall, \& A. Cribb (Eds.), Changing teacher professionalism: International trends, challenges and ways forward (pp. 19-30). London, New York: Routlege. 
Freidson, E. (2001). Professionalism: The third logic. Chicago: Polity Press.

Goodson, I. F. (2003). Professional knowledge, professional lives: Studies in education and change. Maidenhead, Philadelphia: Open University Press.

Goodson, I. F. (2010). Times of educational change: Towards an understanding of patterns of historical and cultural refraction. Journal of Education Policy, 25(6), 767-775. https://doi.org/10.1080/02680939.2010.508179

Goodson, I., Moore, S., \& Hargreaves, A. (2006). Teacher nostalgia and the sustainability of reform: The generation and degeneration of teacher' mission, memory, and meaning. Educational Administration Quarterly, 42(1), 42-61. https://doi.org/10.1177/0013161X05278180

Grootings, P. (2009). Facilitating policy-learning: Active learning and the reform of educational systems in transition countries. In R. Maclean \& D. Wilson (Eds.), International handbook of education for the changing world of work: Bridging academic and vocational learning (pp. 499-512). Dordrecht, New York: Springer. https://doi.org/10.1007/978-1-4020-5281-1_33

Hargreaves, A. (2006). Four ages of professionalism and professional learning. In H. Lauder, P. Brown, J.-A. Dillabough, \& A. H. Halsey (Eds.), Education, globalization, and social change (pp. 672-691). Oxford: Oxford University Press.

Hargreaves, A., \& Goodson, I. (2006). Educational change over time? The sustainability and non-sustainability of three decades of secondary school change and continuity. Educational Administration Quarterly, 42(1), 3-41. https://doi.org/10.1177/0013161X05277975

Harris, R., Simons, M., \& Clayton, B. (2005). Shifting mindsets: The changing work roles of vocational education and training. Adelaide: Australian National Training Authority.

Hoyle, E. (1974). Professionality, professionalism and control in teaching. London Educational Review, 3(2), 13-19.

Hoyle, E. (2008). Changing conceptions of teaching as a profession: Personal reflections. In D. Johnson \& R. Maclean (Eds.), Teaching: Professionalization, development and leadership (pp. 285-304). Bonn: Springer. https://doi.org/10.1007/978-1-4020-8186-6_19

Hughes, J., \& Attwell, G. (2010). Training needs of trainers and VET teachers in the UK. In S. Kirpal (Ed.), Changing roles and competences of VET teachers and trainers. Final Report / Vol. II: National summaries of interview results (pp. 7-22). Germany: University of Bremen.

Johns-Shepherd, L., \& Gowing, E. (2007). Beyond the classroom door, beyond the school gates: The imperative for school-to-school networks for professional learning. In J. Pickering, C. Daly, \& N. Pachler (Eds.), New designs for teachers' professional learning (pp. 116-132). London: University of London.

Kats, E., van Lakerveld, J., \& Smit, H. (2010). Changing roles and competences in vocational training and professional development - Reflections on the interviews with Dutch educational professionals. In S. Kirpal (Ed.), Changing roles and competences of VET teachers and trainers. Final Report / Vol. II: National summaries of interview results (pp. 23-33). Germany: University of Bremen.

Kirpal, S. (2011). Emerging roles and competence requirements of teaching and training practitioners - A European perspective. In S. R. Kirpal (Ed.), National 
pathways and European dimensions of trainers' professional development (pp. 27-44). Frankfurt am Main: Peter Lang.

Kutseõpetaja statuut (1995). RTL 1995, 49, 0. Külastatud aadressil http://www.estlex.ee/tasuta/?id=8\&aktid=15092\&fd=1\&asutus=47\&grupp=3.

Kutseseadus (2000). Riigi Teataja I 2001, 3, 7. Külastatud aadressil https://www.riigiteataja.ee/akt/26716.

Liivik, R., \& Sirk, M. (2015). Muutused kutseõppeasutuste õpilaskonnas ja nende mõju kutseõpetaja pedagoogilisele tegevusele. T. Kuurme (toim.), Kasvatustegelikkuse ajakajalisi peegeldusi: valik kasvatusteaduslikke uurimusi (lk 175-195). Tallinn: Tallinna Ülikooli kasvatusteaduste instituut.

Loogma, K. (2004). Töökeskkonnas õppimise tähendus töötajate kohanemisel töömuutustega (doktoritöö). Tallinn: TPÜ kirjastus.

Loogma, K. (2010). The situation of VET teachers in Estonia. In S. Kirpal (Ed.), Changing roles and competences of VET teachers and trainers. Final Report / Vol. II: National summaries of interview results (pp. 97-116). Germany: University of Bremen.

Loogma, K. (2014). Conceptualizing teachers' professionalism: The case of Estonian lower secondary teachers. In A. Liimets \& M. Veisson (Eds.), Teachers and youth in educational reality (pp. 11-22). Frankfurt am Main: Peter Lang Edition.

Loogma, K. (2016). Europeanization in VET policy as a process of reshaping the educational space. International Journal for Research in Vocational Education and Training, 3(1), 16-28. https://doi.org/10.13152/IJRVET.3.1.5

Loogma, K., Tafel-Viia, K., \& Ümarik, M. (2013). Conceptualizing educational changes: A social innovation approach. Journal of Educational Change, 14(3), 283-301. https://doi.org/10.1007/s10833-012-9205-2

Moomaw, W. E. (2005). Teacher-perceived autonomy: A construct validation of the teacher autonomy scale (Doctoral dissertation). The University of West Florida. Retrieved from http://purl.fcla.edu/fcla/etd/WFE0000027.

Müller, J., Norrie, C., Hernández, F., \& Goodson, I. (2010). Restructuring teacher' work-lives and knowledge in England and Spain. Compare: A Journal of Comparative and International Education, 40(3), 265-277.

https://doi.org/10.1080/03057920902830061

Noordegraaf, M. (2007). From "pure" and "hybrid" professionalism: Present-day professionalism in ambiguous public domains. Administration \& Society, 39(6), 761-785. https://doi.org/10.1177/0095399707304434

Pachler, N. (2007). Teacher developement. In J. Pickering, C. Daly, \& N. Pachler (Eds.), New designes for teachers' professional learning (pp. 242-268). London: University of London.

Pearson, L. C., \& Moomaw, W. (2006). Continuing validation of the teaching autonomy scale. The Journal of Educational Research, 100(1), 44-51. https://doi.org/10.3200/JOER.100.1.44-51

Pickering, J. (2007). Teachers' professional development: Not whether or what, but how? In J. Pickering, C. Daly, \& N. Pachler (Eds.), New designs for teachers' professional learning (pp. 192-216). London: University of London.

Rekkor, S. (2014). Kutsehariduse õppekavade reformid Eestis. H. Voolaid (toim.), Kutsehariduse kooliõppekavade koostamise ja arendamise käsiraamat (lk 9-17). Tartu: Innove. 
Rekkor, R., Ümarik, M., \& Loogma, K. (2013). Adoption of national curricula by vocational teachers in Estonia. Journal of Vocational Education and Training, 65(4), 489-506. https://doi.org/10.1080/13636820.2013.841277

Sahlberg, P. (2010). Rethinking accountability in a knowledge society. Journal of Educational Change, 11(1), 45-61. https://doi.org/10.1007/s10833-008-9098-2

Singh, M. (2011). Investigating the changes in teacher professional learning: A case study of QMEA schools. Cross-Cultural Communication, 7(2), 63-72. https://doi.org/10.3968/j.ccc.1923670020110702.007

Sirk, M., Liivik, R., \& Loogma, K. (2016). Changes in the professionality of vocational teachers as viewed through the experiences of long-serving vocational teachers in Estonia. Empirical Research in Vocational Education and Training, 8(13), 1-26. https://doi.org/10.1186/s40461-016-0039-7

Spillane, J. P., Reiser, B. J., \& Reimer, T. (2002). Policy implementation and cognition: Reframing and refocusing implementation research. Review of Educational Research, 72(3), 387-431. https://doi.org/10.3102/00346543072003387

Susimetsä, M. (2010). Finland. In S. Kirpal (Ed.), Changing roles and competences of VET teachers and trainers. Final Report / Vol. II: National summaries of interview results (pp. 71-78). Germany: University of Bremen.

Tafel-Viia, K., Loogma, K., Lassur, S., \& Roosipõld, A. (2012). Networks as agents of innovation: Teacher networking in the context of vocational and professional higher education reforms. Vocations and Learning, 5(2), 175-193. https://doi.org/10.1007/s12186-012-9077-x

The Copenhagen Declaration (2002). Enhanced EU cooperation in vocational education and training. Retrieved from http://eur-lex.europa.eu/legal-content/EN/TXT/?uri=URISERV:ef0018.

Tutschner, R. (2010). The changing roles and competences of VET practitioners in Germany - IVET teachers and trainers' perceptions of changes in their work. In S. Kirpal (Ed.), Changing roles and competences of VET teachers and trainers. Final Report / Vol. II: National summaries of interview results (pp. 35-54). Germany: University of Bremen.

Van Ruler, B. (2005). Commentary: Professionals are from Venus, scholars are from Mars. Public Relations Review, 31(2), 159-173. https://doi.org/10.1016/j.pubrev.2005.02.022

Vähäsantanen, K., \& Eteläpelto, A. (2009). Vocational teachers in the face of a major educational reform: Individual ways of negotiating professional identities. Journal of Education and Work, 22(1), 15-33. https://doi.org/10.1080/13639080802709620

Wallace, M. (2003). Managing the unmanageable? Coping with complex educational change. Educational Management Administration \& Leadership, 31(1), 9-29. Ümarik, M. (2015). Adopting reform policies in vocational education and training: The case of post-Soviet Estonia (Doctoral dissertation). Tallinn: Tallinna Ülikool.

Ümarik, M., Loogma, K., \& Tafel-Viia, K. (2014). Restructuring vocational schools as social innovation? Journal of Educational Administration, 52(1), 97-115. https://doi.org/10.1108/JEA-08-2012-0100

Ümarik, M., \& Rekkor, S. (2013). Diversification of students and professional roles of vocational teachers: Teachers' individual approaches to negotiate work identities. In J. Mikk, M. Veisson, \& P. Luik (Eds.), Change in teaching and learning, 5 (pp. 9-26). Frankfurt am Main: Peter Lang. 


\title{
Collaboration as the central factor determining vocational teachers' professionality
}

\author{
Meidi Sirk $^{\mathrm{a} 1}$, Meril Ümarik ${ }^{\mathrm{a}}$, Krista Loogma ${ }^{\mathrm{a}}$, Katrin Niglas ${ }^{\mathrm{b}}$ \\ ${ }^{a}$ School of Educational Sciences, Tallinn University \\ ${ }^{b}$ Tallinn University
}

\begin{abstract}
Summary
Vocational teachers have faced radical changes in their work since Estonia regained its independence. While previously, teachers specialised in teaching theory or practical training, now vocational teachers need to teach both and also integrate vocational with general subjects. Moreover, in addition to teaching, other time-consuming tasks, such as administrative tasks, course instructions, preparing students for skills competitions and others, has become part of the role of vocational teachers. Therefore, experienced teachers tend to feel that teaching now has secondary importance in their professional work (Sirk et al., 2016). The variety among students ranging from those without general education to those with higher education has been regarded as the biggest challenge by vocational teachers. Little support from the students' homes and serious learning and behavioural problems among vocational students at the upper-secondary level after basic school (Liivik \& Sirk, 2015; Sirk et al., 2016) increasingly demands social-pedagogical and psychological competencies from teachers (Cort, 2011; Harris et al., 2005; Kirpal, 2011). Changes related to students have brought new work roles for vocational teachers, such as supervisor, mentor, councillor or social worker (Cort \& Rolls, 2010; Hughes \& Attwell, 2010; Kats et al., 2010; Sirk et al., 2016; Susimetsä, 2010; Tutschner, 2010; Ümarik \& Rekkor, 2013) and influenced their professionality (Sirk et al., 2016) and professional identity (Ümarik \& Rekkor, 2013).

We can argue that teachers now need to teach in a way for which they have not been prepared (Hargreaves, 2006). Moreover, constant changes demand continuous professional development. Collaborative learning - exchange of the best practices and learning materials has become wide-spread (Sirk et al., 2016). Collaborative learning and co-operation in work practices has been regarded as the most effective way to adapt to the changes (Hargreaves, 2006). Previous studies have demonstrated that those teachers who are professionally highly
\end{abstract}

School of Educational Sciences, Tallinn University, Narva mnt 25, 10120 Tallinn, Estonia; meidi.sirk@tlu.ee 
networked tend to adopt educational changes resulting from various reform policies more easily, and hold more positive attitudes towards the changes than less networked teachers, as they understand the aims of the new requirements (Rekkor et al., 2013; Tafel-Viia et al., 2012; Vähäsantanen \& Eteläpelto, 2009; Ümarik \& Rekkor, 2013). Changes in vocational teachers' work and work roles indicate the need to reconceptualise vocational teacher professionalism.

Hargreaves (2006) in his model distinguishes four ages of professionalism and argues that we have stepped from the period of teacher autonomy to the period of collegiality. This view is in line with Hoyle (1974), who regards professionality as one attribute of professionalism related to individual elements of teaching work, such as the skills, competences and procedures applied in practice. In his model of restricted and extended professionality, the restricted professional rather applies an intuitive approach and experience than theory in his/her work and tends to hold a narrow classroom-centred perspective in his/her work. The extended professional, on the other hand, has a broader view about the role of education in society, values theoretical knowledge, and conceptualises his/her work and role in shaping student lives. Moreover, the extended professional is involved in collaborative learning and decisionmaking, the development of curricula, and the selection of methods and materials. According to Hoyle (1974), collaboration inevitably decreases teacher autonomy. However, other authors (Evetts, 2002; Pearson \& Moomaw, 2006) offer an alternative approach to autonomy that is not based on individual but collective decision-making. Results of our previous studies (Rekkor et al., 2013; Tafel-Viia et al., 2012) tend to support the arguments made by Hargreaves (2006) that in the age of collegial professional, there are also teachers who tend to ignore collaboration and prefer to work in isolation. Therefore, our paper's aim is to understand VET teachers' professionality in the age of collegiality. The main research question explores what groups can be identified among Estonian vocational teachers based on Hoyle's model of restricted and extended professionality, and how do different groups differ in terms of work satisfaction and perceptions regarding the status of vocational education in society.

We base our analysis on data from a quantitative survey conducted among 501 vocational teachers in Estonia. By K-means clustering, three groups of teachers were formed: 1 ) extensively networked professionals (27\%), involving also networking outside their own school; 2) collaboration-detached professionals (28\%) and 3) school-centred professionals (45\%).

Subsequently, the clusters formed have been described according to their socio-demographic background. Moreover, differences between groups have been analysed in terms of work satisfaction and perceptions of the status of vocational teachers. The statistically significant differences between the groups 
have been controlled using analysis of variance (ANOVA) with Bonferroni and Chi-square tests.

Based on our results we can argue that changes in vocational education have involved differentiation among vocational teachers based on collaboration practices. First, extensively networked professionals (27\%) were involved in intensive co-operation in their school, but also in learning collaboration outside the school. The study revealed that although this group of teachers is highly involved in collaborative work and learning practices they still perceive autonomy in their work, are satisfied with their work and the vocational teacher profession. This group involves more Estonian than Russian speakers and more teachers of vocational subjects than general ones. Secondly, collaboration-detached professionals (28\%) were characterised by low involvement in co-operation practices and detachment from wider professional networks although perceiving themselves as self-efficient in shaping student lives through their work. Among the collaboration-detached group, there are more Russian speaking teachers, teachers of general education and male teachers. The majority of vocational teachers fell into the school-centred professionals group (45\%), whose co-operation practices are mainly limited to their own school context, and are less involved in wider co-operation networks. In respect to the co-operation spectrum, all groups of teachers perceive autonomy in their work. However, extensively networked professionals are more satisfied with their work and more committed to their profession than other groups. On the other hand, the status of vocational teachers as perceived does not differ statistically significantly between different groups of vocational teachers.

\section{Acknowledgements}

The article is part of the national research project IUT18-2 "Teachers' professionality and professionalism in changing context (1.01.2014-31.12.2019)", supported by the Estonian Research Council.

Keywords: educational changes, professionality, professionalism, vocational teachers, cluster analysis 